\title{
Rates and Causes of Deforestation in Indonesia: Towards a Resolution of the Ambiguities
}

William D.Sunderlin and Ida Aju Pradnja Resosudarmo

CENTER FOR INTERNATIONAL FORESTRY RESEARCH office address: Jalan Gunung Batu 5 Bogor 16001 Indonesia mailing address: P.O.Box 6596, JKPWB Jakarta 10065 Indonesia tel.: $+62(251) 34-3652$ fax: +62(251) 32-6433

email: cifor@cgnet.com 


\section{The CGIAR System}

The Consultative Group on International Agricultural Research (CGIAR) is an informal association of 41 public and private sector donors that supports a network of sixteen international agricultural research institutes, CIFOR being the newest of these. The Group was established in 1971. The CGIAR Centers are part of a global agricultural research system which endeavour to apply international scientific capacity to solution of the problems of the world's disadvantaged people.

\section{CIFOR}

CIFOR was established under the CGIAR system in response to global concerns about the social, environmental and economic consequences of loss and degradation of forests. It operates through a series of highly decentralised partnerships with key institutions and/or individuals throughout the developing and industrialised worlds. The nature and duration of these partnerships are determined by the specific research problems being addressed. This research agenda is under constant review and is subject to change as the partners recognise new opportunities and problems. 



\section{CONTENTS}

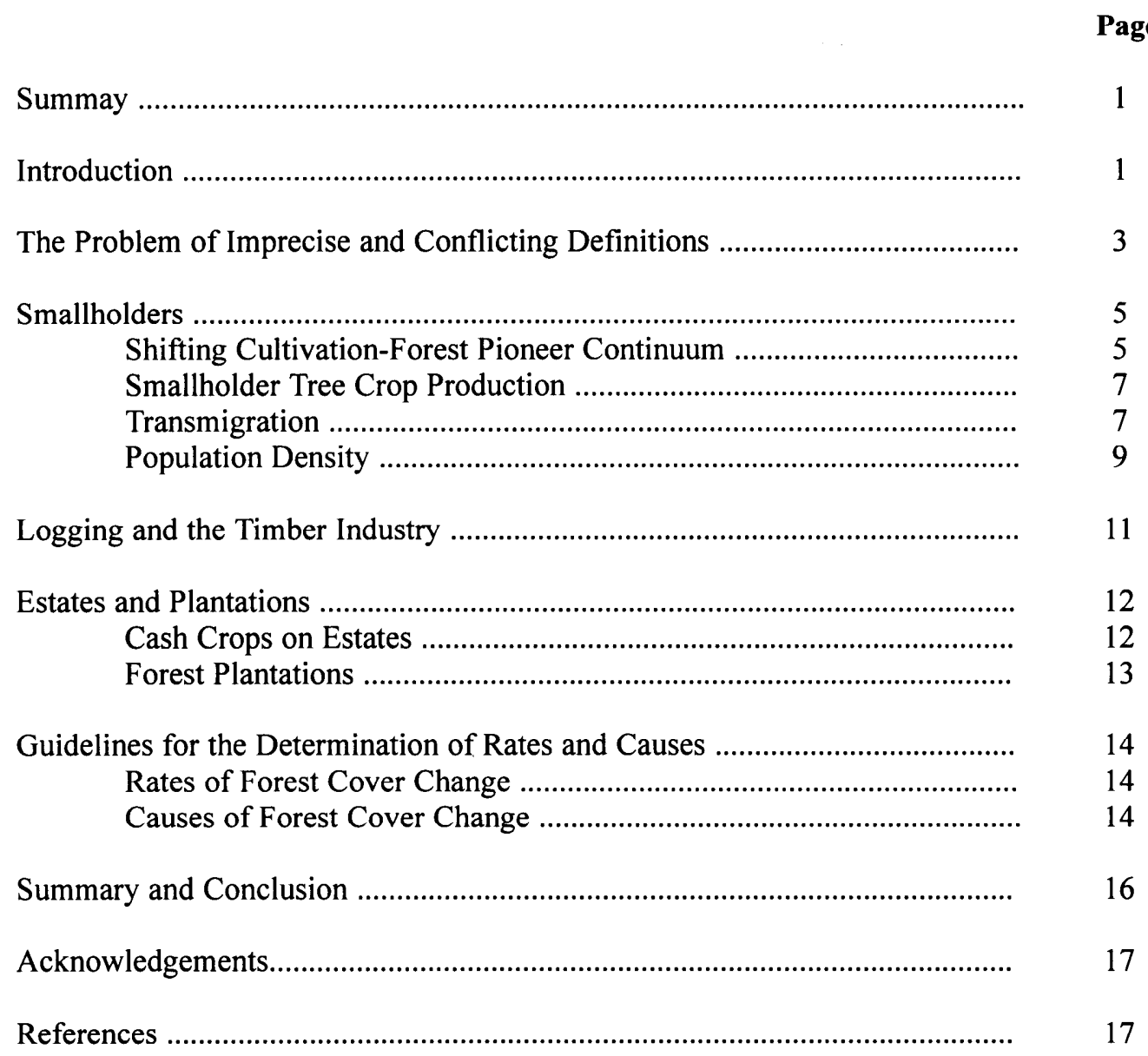




\title{
RATE AND CAUSES OF DEFORESTATION IN INDONESIA: TOWARDS A RESOLUTION OF THE AMBIGUITIES
}

\author{
William D. Sunderlin and Ida Aju Pradnja Resosudarmo
}

\begin{abstract}
Summary
There have been several major research efforts on the rate and causes of Indonesia 's deforestation in recent years and much associated literature, but there is still no consensus in the research community on these issues. This paper reviews the areas of uncertainty and confusion, and proposes questions that must be answered to get a better grasp of the subject. Among the key questions are: (1) How are we to define 'forest ", "deforestation" and "agency" in the context of Indonesia?; (2) What are the socio-economic characteristics and land-use practices of the various agents that have been lumped under the term "shifting cultivation"? (3) Is the relationship between increasing population density and loss of forest cover causal or incidental?, (4) Why do some concessionaires appear to manage their sites relatively well, while many others do not?; (5) What have been the net forest cover effects of macro-economic restructuring and changes of commodity prices since the early 1980s? Guidelines are proposedfor improved research on the rate and causes of forest cover change. The paper closes noting the need to rise above a tendency to seek mono-causal explanations. Cogent explanations will necessarily be complex, since the causes reside in long-standing and broad socio-economic forces.
\end{abstract}

\section{INTRODUCTION}

Indonesia ranks third (behind Brazil and Zaire) in its endowment of tropical rainforests, possessing $10 \%$ of what remains in the world of this resource. Official estimates of the area of forested land in Indonesia diverge widely. The sixth Five-Year Development Plan (REPELITA VI, 1994/95-1998/99) says there were 92.4 million ha of forest land in 1993 (RI 1994: 312). This is $48.1 \%$ of the total land area. The National Forest Inventory, based on 1986-91 satellite data, estimates there are 120.6 million ha of forested land covering $69 \%$ of the land area (excluding Java) (GOI/FAO 1996: 17-18). The approximate distribution of Indonesia's forest cover is as follows: Kalimantan (32.0\% of the total); Irian Jaya (29.9\%); Sumatra (20.8\%); Sulawesi (9.7\%); Maluku (5.5\%); and other (2.1\%) (derived from GOI/FAO 1996: 36).

Dating from the mid-1960s, commercial exploitation of forests in the outer islands ${ }^{1}$ has grown rapidly and Indonesia is now one of the world leaders in the export of tropical timber (notably of plywood). In 1996, 445 logging concessions were operating on $54,060,599$ ha. $^{2}$ In 1994, wood and wood products produced about US\$ 5.5 billion in export revenue for Indonesia, about $15 \%$ of the total (Economist Intelligence Unit 1995b: 3). There are approximately 700,000 people employed in the formal forest sector (World Bank 1995: 1).

In the course of the development of the timber industry, there has been a marked increase in the extent and rate of disappearance of Indonesia's forest cover. A 1990 FAO study found that the forest cover of the country has been reduced from $74 \%$ to $56 \%$ in the space of 30-40 years (FAO 1990: 3). The World Bank (1990: xx), referring to research by FAO, notes the following progression in the estimate of annual deforestation: in the 1970s, 300,000 ha/year; in 1981, 600,000 ha/year; in 1990, one million ha/year.

It is tempting to conclude that the growth of the timber industry explains the perceived rapid acceleration of forest cover loss, since the two phenomena occur over the same period of time. An alternative explanation, however, holds that deforestation in the outer islands is principally a response to the growth of population density and the growth in the number of smallholders in those areas. Data on population density in Indonesia show a strong negative correlation with forest cover (FAO 1990: 10; Barbier et al. 1993: 7; Fraser 1996). ${ }^{3}$

There are essentially two poles in the ongoing debate over the causes of deforestation in Indonesia (Table 1). On the one hand, there are explanations that see smallholder production and the growing number of such producers as the main cause of deforestation (FAO 1990; World Bank 1990; Barbier et al. 1993; Fraser 1996). These explanations tend to view civil society (i.e., non-state actors), and notably smallholders, as a lead force in forest cover removal. On the other hand there are explanations that, while acknowledging a significant role of smallholder production in deforestation, give greater emphasis to the

\footnotetext{
1 The term "outer islands" refers to the area of Indonesia outside of Java, Madura and Bali.

2 Data from personal communication, Waskito Suryodibroto, Secretary to the Director General, Directorate General for Forest

Exploitation, Department of Forestry, Jakarta, Indonesia, November 21, 1996.

3 Flint (1994: 1043) demonstrates this correlation for South-east Asia as a whole.
} 
Table 1: Change over time in views on causes of deforestation in Indonesia

\begin{tabular}{|c|c|c|c|c|c|c|c|}
\hline \multirow{4}{*}{ SOURCE } & \multicolumn{7}{|c|}{ TYPE OF CAUSE } \\
\hline & \multicolumn{5}{|c|}{ AGENT } & \multicolumn{2}{|c|}{ UNDERLYING } \\
\hline & \multicolumn{3}{|c|}{ smallholder } & \multirow[b]{2}{*}{$\begin{array}{l}\text { plantations } \\
\& \text { tree } \\
\text { crops }\end{array}$} & \multirow[b]{2}{*}{$\begin{array}{l}\text { timber } \\
\text { industry }\end{array}$} & \multirow[b]{2}{*}{$\begin{array}{l}\text { government } \\
/ \text { politics }\end{array}$} & \multirow[b]{2}{*}{$\begin{array}{c}\text { economic } \\
\text { development }\end{array}$} \\
\hline & $\begin{array}{c}\text { shifting } \\
\text { cultivation }\end{array}$ & $\begin{array}{c}\text { spontaneous } \\
\text { transmigrants }\end{array}$ & $\begin{array}{c}\text { regular } \\
\text { transmigrants }\end{array}$ & & & & \\
\hline $\begin{array}{l}\text { World Bank } \\
1990\end{array}$ & & & & & & & \\
\hline \multicolumn{8}{|l|}{ FAO 1990} \\
\hline \multicolumn{8}{|l|}{ Dick 1991} \\
\hline WALHI 1992 & $\begin{array}{c}\text { effects } \\
\text { overstated }\end{array}$ & & & & & & \\
\hline $\begin{array}{l}\text { Barbier et al. } \\
1993\end{array}$ & \multicolumn{3}{|c|}{ 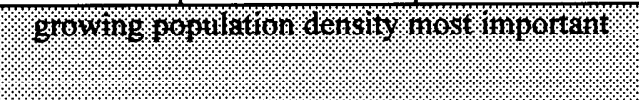 } & & & & \\
\hline Ascher 1993 & & & & & & Wovernmenl. & 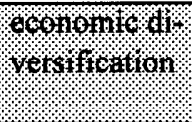 \\
\hline \multicolumn{8}{|l|}{ Porter 1994} \\
\hline Dauvergne 1994 & & & & & $\begin{array}{c}\text { effects } \\
\text { understated }\end{array}$ & & \\
\hline Thiele 1994 & \multicolumn{3}{|c|}{ effects overstated } & & $\begin{array}{c}\text { effects } \\
\text { understated }\end{array}$ & & \\
\hline $\begin{array}{l}\text { World Bank } \\
1994\end{array}$ & $\begin{array}{c}\text { effects } \\
\text { overstated }\end{array}$ & & & & $\begin{array}{c}\text { effects } \\
\text { understated }\end{array}$ & & \\
\hline Angelsen 1995 & $\begin{array}{c}\text { effects } \\
\text { overstated }\end{array}$ & & & & & governinerist: & progenours. \\
\hline MOF 1995 & $\begin{array}{c}\text { effects } \\
\text { overstated }\end{array}$ & & & & & & \\
\hline Ross 1996 & & & & & & (Moling & \\
\hline Fraser 1996 & Poptiation & & & $\begin{array}{c}\text { effects } \\
\text { overstated }\end{array}$ & & & \\
\hline $\begin{array}{l}\text { Hasanuddin } \\
1996\end{array}$ & $\begin{array}{c}\text { small- } \\
\text { holders } \\
\text { blameless }\end{array}$ & & & & & & \\
\hline Dove 1996 & $\begin{array}{c}\text { effects } \\
\text { overstated }\end{array}$ & & & & & \multicolumn{2}{|c|}{ BatFon } \\
\hline
\end{tabular}

Shaded area indicates form of agency assumed to have the largest role in deforestation.

role of government and its development projects, and to the timber sector (Dick 1991; WALHI 1992; Ascher 1993; Dauvergne 1994; Porter 1994; Thiele 1994; World Bank 1994; Angelsen 1995; Dove 1996; Hasanuddin 1996; Ross 1996).

Table 1 shows the shifting "centre of gravity" of explanations in recent years. The World Bank and FAO postulated a central role for shifting cultivation in 1990. Most subsequent analyses contend the role of shifting cultivation has been over-estimated, and that of the timber sector has been under-estimated. Central to the new line of reasoning is the claim that the timber industry has a significant indirect role in deforestation, by logging lands that are subsequently occupied by smallholders.

It is noteworthy that there has been a "sea change" in the posture of the World Bank, one of the key formal actors in the debate. In 1990, the World Bank (1990: xxi) estimated the annual rate of deforestation to be between 700,000 and $1,200,000$ ha, viewed 
smallholder conversion as accounting for 350,000 650,000 ha of the total, and underscores its concern about shifting cultivation. In 1994, the World Bank (1994: ix, 19) identified management of forest concessions in the outer islands as one of the "highest priority" environmental issues facing the country and notes that the role of swidden agriculture in deforestation had been over-emphasised in previous studies.

The World Bank (1994: 51) refers to the work of Dick (1991), who claims that programmes sponsored by the government (transmigration, estate crops, logging) explain $67 \%$ of all deforestation.

The dramatic change in the posture of the World Bank should not be interpreted as a sign that the research community is closing in on understanding the extent and causes of deforestation in Indonesia. Quite to the contrary, it seems that although crucial pieces of knowledge have been accumulated, many uncertainties and puzzles remain. The World Bank (1994: 19) acknowledges that estimates of the annual rate of deforestation are based on weak data. Rather than offering an updated estimate of its own, the Bank instead reports the wide variation of estimates put forward by others, ranging from 263,000 ha/year to 1,3/15,000 ha/year (World Bank 1994: 52). The Bank appears ambiguous on the issue of agency in deforestation. On the one hand, it elevates the role of logging and government programmes in the process of deforestation and downplays that of swidden agriculture; on the other hand, it says that small-scale agriculture is the "largest cause of deforestation" (World Bank 1994: 53).

Review of some of the main pieces of literature on deforestation in Indonesia reveals there are two primary reasons for weakness of the knowledge base on the subject. First, there is a lack of appropriate and/or reliable primary data on the rate and causes of forest cover change. ${ }^{4}$ Dick (1991: 32) observes that, given this limitation, assessments of the extent and causes of deforestation in Indonesia are at best "semi-educated guesses". Second, commentators on the subject use such terms as "deforestation" and "shifting cultivation" to mean various things. This, as we shall see, introduces a great deal of confusion into the debate.

The most useful step toward enhancing the knowledge-base on deforestation in Indonesia is to conduct a critical review of the available literature. In this way we can place a "confidence interval" on relevant parts of past analyses, define topics that require further inquiry, and propose guidelines for resolving ambiguities.
This paper will review the literature through the following steps. First, the issue of unclear conceptualisation of the term "deforestation" and "agent of deforestation" will be addressed. Second, discussions of the various causes of forest cover change will be analysed. In sequence these will be: smallholders (shifting cultivation and "forest pioneer" cultivation; smallholder tree crop production; regular transmigration; spontaneous transmigration; population growth); logging and the timber industry; plantations and estates; and macro-economic policies; and other forms of causation that have received relatively little attention in the literature. Third, guidelines will be proposed for improved research on the rate and causes of forest cover change. The paper will close summarising the key issues requiring further research.

\section{THE PROBLEM OF IMPRECISE AND CONFLICTING DEFINITIONS}

Estimates of the area of annual average deforestation in Indonesia vary widely, ranging from a low of 263,000 ha (TAG 1991) to a high of 2,400,000 ha (Hasanuddin 1996) (see Table 2). Several authors have observed that estimates of deforestation in Indonesia are undermined by unclear or diverging uses of the term "deforestation". Among the most vocal on this subject are Dick (1991), Soemarwoto (1992), Saharjo (1994) and Angelsen (1995). $\quad$ Lack of specificity in use of the term "deforestation" facilitates selective interpretation of data and therefore severely distorts the issue. As we will see below, in the worst case, one person's "deforestation" can be another's "reforestation". A related problem is how one conceptualises or defines the "agent" of deforestation. Following are some of the main difficulties in use of the terms "deforestation" and "agent of deforestation".

(1) Does “deforestation" refer to just permanent, or both permanent and temporary removal of forest cover? Two of the key studies (FAO 1990; World Bank 1990) implicitly assume that both permanent and temporary removal of forest cover constitute deforestation. In so doing, they include as "deforestation" large areas of shifting cultivation that will eventually return to secondary forest status. This definition, therefore, greatly enlarges both the area assumed to be deforested and the role of shifting cultivation in overall deforestation.

4 The FAO (1990) deforestation estimate relies on various forest cover assessments from different years; forest cover change was then extrapolated at the provincial level on the basis of population density data (Sutter 1989: 101-154). The World Bank (1990: 3 , 147) estimate of deforestation relies on bank calculations and on a survey of wood raw material supply. Reliable estimates of forest cover change require comparison of matched satellite images from multiple years (Downton 1995: 230).

5 Sayer and Whitmore (1991) and Grainger (1993) have noted the difficulty of making international comparisons of estimates of forest cover loss because of varying definitions of key terms and concepts. 
Table 2: Estimates of annual deforestation in indonesia (thousands of ha)

\begin{tabular}{|c|c|c|c|c|c|c|c|c|}
\hline SOURCE OF & \multicolumn{8}{|c|}{ AGENT } \\
\hline ESTIMATE & $\begin{array}{l}\text { Transmig. } \\
\text { Dev't }\end{array}$ & $\begin{array}{l}\text { Estate } \\
\text { Crops } \\
\end{array}$ & $\begin{array}{l}\text { Swamp } \\
\text { Dev't }\end{array}$ & $\begin{array}{l}\text { Spontan.- } \\
\text { Transmig. }\end{array}$ & $\begin{array}{l}\text { Trad'l } \\
\text { Ag. }\end{array}$ & $\begin{array}{l}\text { Forest } \\
\text { Harvest }\end{array}$ & Fires & TOTAL \\
\hline $\begin{array}{l}\text { World Bank } \\
1990\end{array}$ & \multicolumn{3}{|c|}{250} & \multicolumn{2}{|c|}{500} & 80 & 70 & 900 \\
\hline FAO 1990 & 300 & 274 & 85 & \multicolumn{2}{|c|}{461} & 80 & 113 & 1,315 \\
\hline TAG 1991" & 65 & 11.4 & 30.4 & \multicolumn{2}{|c|}{156.5} & $\mathrm{NE}$ & $\mathrm{NE}$ & 262.9 \\
\hline MOF 1992 $^{\mathrm{b}}$ & 300 & 160 & & \multicolumn{2}{|c|}{300} & 77 & 478 & 1,315 \\
\hline Dick 1991 & 78.4 & 11.4 & 30.4 & 178.5 & 135.5 & 120 & 70 & 623 \\
\hline Sukarjo $1996^{c}$ & $\mathrm{NE}$ & $\mathrm{NE}$ & $\mathrm{NE}$ & $\mathrm{NE}$ & $\mathrm{NE}$ & $\mathrm{NE}$ & $\mathrm{NE}$ & 809 \\
\hline $\begin{array}{l}\text { Hasanuddin } \\
1996\end{array}$ & $\mathrm{NE}$ & $\mathrm{NE}$ & NE & $\mathrm{NE}$ & $\mathrm{NE}$ & NE & $\mathrm{NE}$ & 2,400 \\
\hline
\end{tabular}

The top five rows of this table (World Bank 1990 through MOF 1992) are adapted from World Bank (1994: 52). The original was modified to reflect the fact that most sources did not separate the categories "spontaneous transmigration" and "traditional agriculture". The World Bank (1994: 52) table falsely gives the impression this distinction was made. Dick (1991) makes a significant contribution by recognising the distinction. 'NE' signifies 'no estimate.'

${ }^{a}$ TAG 1991.

${ }^{\mathrm{b}}$ MOF 1992.

c Reported in the Jakarta Post, May 29, 1996.

(2) Does "deforestation" refer to the loss of forest cover for all kinds of uses, or does it refer to the loss of forest cover that will never again regenerate for timber production? An implicit definition of deforestation in World Bank 1990 (p.3) is based on the latter view.

(3) Does "deforestation" refer to the removal of forest cover alone, or does it refer as well to the loss of various kinds of forest attributes, such as density, structure and species composition? Saharjo (1994) points out the area deforested is smaller in the former case, larger in the latter. Forest degradation is an important issue with respect to assessing the comparative environmental effects of smallholder agriculture and logging.
Under traditional shifting cultivation, for example, cultivated land is often said to be "deforested", but may return to forest cover at a later date. Loggedover forests are often not considered "deforested", inasmuch as there are still many standing trees after selective felling, however in some cases there may have been considerable loss of various environmental functions of the forest.

(4) Is the "agent of deforestation" the one that removes the forest cover, or the one that subsequently prevents the regrowth of forest cover? If one assumes the former, then logging companies are assigned a larger role in deforestation than otherwise might be the case. If 
one assumes the latter, then agricultural smallholders, who sometimes colonise land that has been first opened up through logging, are assigned a larger role than might otherwise be the case. Some observers have pointed out that it may be practically impossible to disaggregate the causal role of different agents operating in the same locality (e.g., World Bank 1990: xx; Ahmad 1995: 3).

(5) Is the "agent of deforestation" most appropriately defined in terms of the ultimate designated use of cleared forest land, rather than by the actions and intentions of those who actually clear the forest? Barbier et al. (1993: 7) suggest such a line of reasoning, saying that much deforestation in Indonesia occurs on land intended for conversion to agriculture, so a causal role must be assigned to the growth of agriculture.

A related problem is the varied perspectives of observers on the principal value of forests, as in the case of substitution of natural forests by forest plantations. ${ }^{6}$ Commentators representing government or industry might view this trend favourably, inasmuch as timber yields from plantations can be greater per hectare than in natural forests. Commentators representing environmental and forest community interests view the situation quite differently, since this process may harm biodiversity and the interests of forest communities. From the point of view of environmentalists, creation of plantations can be seen as "deforestation", whereas from the point of view of government and industry it might be seen as "reforestation". This concern is captured succinctly in the title of the WALHI/YLBH (1992) document Mistaking Plantations for Indonesia's Tropical Forests. These interest-based positions with respect to different types of forests can lead to different interpretations of the same primary data.

It should be clear that more precise use of key terms and concepts is a pre-condition for raising the quality of research on forest cover change. In section 6 , we urge application of a new methodology for analysing forest cover change developed by FAO (1996). This methodology includes precise definitions for "forest" and "deforestation" which - if applied systematically can help avoid confusion and selective interpretation of forest cover data.

\section{SMALLHOLDERS}

In this section, we review recent literature on the role of rural smallholders in forest cover change in Indonesia. This review covers: the, "shifting cultivation-forest pioneer" continuum; smallholder tree crop production; regular transmigration; spontaneous transmigration; and the role of population density in forest cover loss.

\section{Shifting cultivation-forest pioneer continuum}

"Shifting cultivation" means entirely different things to different people. This terminological confusion undermines efforts to understand the relationship between smallholder farming systems and forest cover change. Weinstock and Sunito (1989: 5) observed that "[e]ven after wading through the plethora of terminology one is confronted with a vast array of definitions of this form of agricultural production, each definition having a different view as to what types of activities should or should not be included". Some uses of the term refer only to traditional, long-fallow, sustainable systems of cultivation; this practice is often said to be associated with the conservation of primary forests. Other authors use "shifting cultivation" to mean practices of rotational agriculture that may or may not have long fallows, and that may or may not be associated with long-term conservation of forests. Still others equate "shifting cultivation" with smallholder agriculture generally in the outer islands - a use of the term that neglects the fact that many smallholders do not practise any systematic form of rotations.

Weinstock and Sunito (1989: 20-21) suggest a fundamental distinction between "shifting cultivators" and "forest pioneers". " "Shifting cultivators" are defined as people "who practice a form of rotational agriculture with a fallow period longer than the period of cultivation. Unless faced with population pressure or other constraints, land is used only one to three years and fallowed for a relatively long period (up to twenty or more years)" (p. 20). "Forest pioneers" are defined as people "who may utilise slashing and burning of the existing vegetation but with the primary intention of establishing permanent or semi-permanent agricultural production. Although some subsistence food crops may be planted, the planting of cash crops (most often perennials) is the primary focus of attention. Land is usually not fallowed but is used continuously and is abandoned only after total or near total exhaustion of the native fertility of the soil since there is no long term plan to again return to the same site" (p. 21).

In order to adequately understand the role of smallholders in forest cover change in Indonesia, it is critically important to acknowledge a continuum of farming systems running from traditional shifting cultivation (involving long fallows and long-term forest conservation) at one extreme, and "forest pioneer" cultivation (often involving long-term degradation

\footnotetext{
${ }^{6}$ Durand (1994: 337) notes that different ways of defining primary forest yield significantly different assessments of how much such forests remain in Indonesia.

7 This is parallel to the distinction made by Myers (1995) between "shifting" cultivators and "shifted" cultivators.
} 
and deforestation) at the opposite extreme. In Indonesia, an ideological polarisation exists whereby government representatives and environmental NGO representatives tend not to recognise the continuum.

The government position condemns "forest pioneer" cultivation (perambahan hutan) as environmentally destructive and often does not differentiate it from shifting cultivation. If the government is serious about forest conservation, then it must support those traditional farming systems that are consistent with the aim of long-term forest conservation.* Conversely, environmental NGOs tend to focus their attention on traditional shifting cultivation ${ }^{9}$ to the exclusion of less sustainable farming systems. It appears environmental activists fear that acknowledging unsustainable smallholder farming systems will undermine their claim that people at the forest margin possess wisdom (kearifan) in forest management. Acknowledgement of the full continuum of farming systems would strengthen, not weaken, the NGO position for two reasons. First, it would demonstrate recognition of the complexity of rural social change. Second, it would demonstrate concern for forest pioneers, who are every bit as much victims in the process of rapid social change as are shifting cultivators.

An important milestone in better understanding the role of shifting cultivation in deforestation was achieved through Dick's (1991) critique of the World Bank (1990) and FAO (1990) studies. On the basis of the following calculation, the World Bank (1990) asserted that shifting cultivation has by far the largest role in deforestation. The area reported to be under shifting cultivation for three provinces of Indonesia in 1990 was 14 million ha in Sumatra, 11 million ha in Kalimantan and 2 million ha in Irian Jaya (RePPProT data, as cited in World Bank 1990: 3). The total area of 27 million ha expands at the annual rate of $2 \%$ implying, according to the World Bank (1990: 3), deforestation of roughly 500,000 ha per year - by far the largest cause of deforestation. FAO's (1990) assumptions were approximately the same.

Dick (1991) criticised the underlying assumptions of these studies pointing out that they lump together under the terms "smallholder conversion" or "shifting cultivation" both "traditional shifting cultivation", which he views as having relatively benign practices, and "spontaneous transmigration" which he views as having unsustainable practices and accounting for the largest share of deforestation 10. He says that given this distinction, traditional shifting cultivators account for $21 \%$ of total deforestation, rather than the largest share, as claimed in the World Bank and FAO studies (p. 32). He believes that even this, however, overstates the contribution of traditional shifting cultivation to deforestation because many of the forests they clear are part of a long-standing rotation on clan lands (p. 32). He points out, moreover, that traditional shifting cultivators "lack the tools necessary to convert all but the most open primary forests" (p. 27).

The later World Bank assessment of deforestation, as mentioned earlier, has a much more favourable outlook on the practice of traditional shifting cultivation. The report states that shifting cultivation may be less damaging than previously thought (World Bank 1994: 19). Colfer with Dudley's (1993) research on four forest communities in East Kalimantan also encourages a more favourable outlook on traditional shifting cultivators, pointing out that they are capable of sustainable resource management and that their agricultural systems, although producing low yields of rice, actually produce a wide range of valuable goods (timber, NTFPs, foods, medicines) that tend to be overlooked in other studies.

There is considerable lack of clarity, however, as to whether traditional shifting cultivators are a significant presence in the outer islands. The World Bank (1994: 19) refers to recent research in claiming that "traditional communities may be much larger than previously thought". Other observers, however, state that traditional shifting cultivators are few in number and are undergoing rapid transformation of their farming systems. Tomich and van Noordwijk (1995: 3) say that traditional shifting cultivation has "virtually disappeared" in Sumatra. Potter (1993: 109) refers to a WWF study showing that "traditional" systems have been modernising, for example with the use of chainsaws. Kartawinata et al. (1989: 603) observe that in some areas nominally under shifting cultivation in East Kalimantan, producers established perennial crops that were maintained for ten or more years.

What are we to make of such widely diverging views on the characteristics of the basic characteristics of shifting cultivation - and more generally of smallholders - in the outer islands of Indonesia? It is clear that understanding the process of forest cover change in Indonesia would be well served by more

\footnotetext{
${ }^{8}$ See Zerner (1992) for an argument in support of this position.
}

9 NGO activists have appropriately insisted on using the term "rotational agriculture" (perladangan gilir-balik) instead of "shifting
cultivation" to describe traditional and sustainable long-fallow swidden cultivation. They reject the insinuation - implied in the
term "shifting" - that these cultivators are fundamentally nomadic and lay claim to forest lands in a haphazard manner. While this
terminological innovation is useful, it should not be used to disguise the fact that there are nomadic systems of forest use.

${ }^{10}$ Dick (1991: 30) also points out that the World Bank and FAO studies used the entire RePPProT estimate of area of land under shifting cultivation, including brush/shrub and grassland, to estimate deforestation. He says this is not valid because there are many natural and long-standing grasslands and shrublands, and because certain agriculturists have farmed these areas for a long time. 
careful categorisation and also characterisation of various kinds of smallholders in forest communities. Weinstock and Sunito (1989: 37-38) found that information is needed in the following areas: (1) land under shifting cultivation classified according to different land forms (slope, etc.); (2) rates of change in the area of shifting cultivation over time; (3) changes in patterns of shifting cultivation over time; and (4) data on the inflow of pioneer settlers along logging roads and the impact they have had on forest lands. These kind of data, as well as data on tree crop producers (see below), would be quite helpful. Recent research has made inroads into this area of knowledge, but much remains to be done. ${ }^{11}$

\section{Smallholder tree crop production}

In addition to "shifting cultivators" and "forest pioneers", we must distinguish another basic farming system category in the outer islands: smallholder tree crop producers. Smallholder tree crop production is often understood within the general term "shifting cultivation", because many shifting cultivators produce tree crops. However, tree crop production should be seen as a distinct analytic category because, although it is strongly associated with shifting cultivation, it tends to be carried out on different kinds of lands and follows an entirely different logic of production (Dove 1993).

Smallholder tree crop production has important implications for forest cover because it is often established in forest clearings and because it has grown greatly in recent years. Barlow and Tomich (1991: 32) note that about $20 \%$ of all agricultural land in Sumatra and Kalimantan is under tree crop production. In 1994, there were 8.89 million ha of the three main tree crops in Indonesia, with the following distribution: rubber (39\%); coconut (41\%); and oil palm (20\%) (PDP 1996). The apportionment of the area of these crops among the major provinces in 1988 was: Sumatra (55\%); Java (15\%); Kalimantan (13\%); Sulawesi (9\%); and Nusa Tenggara (5\%) (Dick 1991: 25). (Note that these data refer to smallholder, estate and plantation production). Indonesia is the world' s second largest producer of natural rubber (about three-quarters produced by smallholders), the second largest producer of palm oil (most from estates), the world's third largest producer of coffee (95\% of production by smallholders), and the fourth largest producer of cocoa (Economist Intelligence Unit 1995a: 29-31). Almost all coconut/copra production in Indonesia is by smallholders (World Bank 1996: 164).
There may be a strong association between smallholder tree crop production and deforestation. Chomitz and Griffiths (1996) found that tree crops, rather than subsistence-oriented shifting cultivation, also plays a major role in deforestation in Indonesia; among various tree crops, rubber appears to have the strongest association to deforestation. Rubber is the largest single earner of agricultural income in Indonesia (US\$1.5 billion in 1994-95) and output value almost doubled in the 1984-1995 period (World Bank 1996: 141). In the 1982-1994 period, production of tree crops increased by the following rates: rubber from 900 to 1,499 tons (66\%); coconut from 1,718 to 2,631 tons $(60 \%)$; and coffee from 281 to 446 tons (55\%) (World Bank 1996: 163).

It is possible the planting of rubber trees may increase in association with their function as a property marker, in areas where land competition is strong. Dove $(1993$ : 142) says that in the Kantu area of West Kalimantan, "[p]lanting of rubber is perhaps most important as a means to establish tenure... this tactic is used against land usurpation not only by fellow tribesmen, but also by the government". Angelsen (1995: 1724-1725) observes that in Riau province, Sumatra, the planting of rubber is a way to "obtain and secure land rights, both according to customary and national law".

\section{Transmigration}

Census data from 1990 show that 108 million $(60 \%)$ of Indonesia's 180 million people live on Java and Madura islands (Economist Intelligence Unit 1995a: 11 ), an area amounting to a mere $7 \%$ of the land surface of the country. Java has one of the densest concentrations of population anywhere in the world. There have been efforts dating back to the early 20th century to encourage families to move from Java to the outer islands in order to relieve population pressure, poverty and land degradation. There are two types of transmigrants: "regular" transmigrants receive full government assistance, whereas "spontaneous" transmigrants receive partial or no government assistance (see below). ${ }^{12}$

There has been a tremendous acceleration in the number of transmigrant families in recent decades. In the period 1950-1979, there were an average of 6,570 regular transmigrant families each year; in the period 1980-1984, the annual average rose to 73,200 families. ${ }^{13}$ Dick (1991: 27-29) observes there is a large

11 See for example: BAPPEDA and PPKD 1995; DepHut 1995; DepTrans and YDWL 1996; Endogeotec Visicon 1996.

12 Strictly speaking, the term "spontaneous" is not appropriate because it implies lack of planning on the part of migrant families (observation made by Chris Bennett through personal communication). Most families put a great deal of thought into their move whether they are fully assisted, partly assisted or unassisted. We reluctantly use the term here to maintain continuity with other discussions of the "regular"/“"spontaneous" distinction (e.g., Dick 1991; World Bank 1994).

${ }^{13}$ Derived from Ministry of Transmigration data in World Bank (1988: xxiii). 
divergence between two sources of information on numbers of transmigrants. In the period 1974-1989, the Ministry of Transmigration (MOT) claims there were 664,000 regular transmigrant families, whereas the Transmigration Advisory Group (TAG) claims there were 323,000 such families (Dick 1991: 28). In this same period, MOT estimates there were 455,000 spontaneous transmigrants; TAG provided no estimate. The approximate distribution of the destinations of transmigrants during REPELITA V (1989/90-1993/94) was: Sumatra (53\%); Kalimantan (23.5\%); Sulawesi (12.6\%); Irian Jaya and Maluku (9.2\%); and other locations $(1.75 \%) .{ }^{14}$ It is projected that in the period 1994-1999 (REPELITA VI), there will be an additional 350,000 regular and 250,000 spontaneous transmigrant families (MOF 1995: 2).

\section{Effects of regular transmigration}

The effects of regular transmigration on forest cover in the outer islands can be classified into three categories: the direct effects of forest cover removal for the transmigration site; the movement of transmigrants from their designated sites because of insufficient incomes; and the land pressures induced by transmigrants on neighbouring non-transmigrant households.

1. Direct forest cover removal. In the mid-1980s, international NGOs said the transmigration programme was responsible for a large share of deforestation in Indonesia (see especially Secrett 1986). In the aftermath of that accusation, some claimed the amount of deforestation attributable to regular transmigration was grossly exaggerated. Whitten (1987: 24l-243) uses provincial data on forest cover and on land clearance for regular transmigration to show that, in 197984 , the official programme led to the conversion of less than $1 \%$ of total forest area. ${ }^{15}$ Whitten estimates that $30-50 \%$ of land cleared for transmigration was originally forested. This correction to past over-estimations runs the risk of going too far in the other direction. An adequate calculation of the environmental impact of transmigration must include an assessment of not only the land cleared for regular settlement, but also of land cleared by regular settlers who are not able to obtain sufficient income on lands assigned to them, and also of land cleared by "spontaneous" settlers. Whitten (1987: 242) notes that "unassisted migrants" outnumber regular ones by roughly two to one, and dismisses the importance of much of the forest conversion, saying it was land that was zoned for conversion to agriculture anyway. While this may be true, it is important to bear in mind that there has been no rational and objective basis for the designation of conversion lands (Dick 1991: 19).

Dick (1991: 30) also challenges exaggerated estimates of forest clearance through transmigration. He contends past estimates of deforestation attributable to regular transmigration have been grossly exaggerated because they assume all land allocated for future transmigration use has been converted to such use, whereas in fact much of this land has not been converted. His own calculation of deforestation attributable to regular transmigration in the period $1979-1989$ is 78,500 ha per year. He bases his calculation on the assumption that about 3.0 ha of forest land are cleared for each regular transmigrant family -2.0 ha of this for agriculture and 1.0 for infrastructure (pp. 31-32). ${ }^{16}$ Dick's calculations err in two ways. First, he equates land clearing with deforestation, yet we know that some of the land cleared for transmigration was not deforested (see above). Second, Dick neglects to follow through on his own insight (p. 29) that 2.0 ha of agricultural land for each family was insufftcient, and that further deforestation will result once the occupants have exhausted the land. The first error tends to over-estimate and the second to under-estimate the amount of forest cleared as a result of regular transmigration.

2. Movement because of insufficient income. Through the mid-1980s, regular transmigration sites aimed to produce food crops (mainly rice) on 2.0 ha of land per family. This proved to be inadequate at many sites both because the area of land was insuffcient, and because the relatively poor soil did not support lowinput rice cultivation. In the mid-1980s it was found that $40-80 \%$ of income in regular transmigrant households was from off-farm work (World Bank 1988: xxvii). Many transmigrants are caught in a vicious cycle, whereby they search for off-site income because site-based income is inadequate, and then the potential of the site-based income is not fully realised because they must work off-site (RePPProT 1990: 41). There is little information available on what proportion of regular transmigrant families turned to shifting cultivation or became forest pioneers. ${ }^{17}$ It has been pointed out that many transmigrants practise an unsustainable form

14 Calculations based on data in DepTrans (1995: Annex 12).

${ }^{15}$ For other references to the effect of transmigration on forest cover, see World Bank (1988: xxxi and 98-99) and McClellan (1992).

16

16 Specifically, the calculation is derived in the following manner. Dick places greater confidence in the TAG data than in the MOT data on numbers of transmigrants, thus assuming there were 261,565 regular transmigrant families in the 1979-1989 (REPELITA III and IV) period. He multiplies this figure by 3.0 ha for each family and assumes a total area deforested for the period of 784,695 ha. He then divides this by 10 to get an annual rate of 78,500 ha.

${ }^{17}$ A 1989 study on five settlement in East Kalimantan found that $23.6 \%$ of transmigrant households shifting cultivation (Fasbender and Erbe 1990: 242-243). 
of shifting cultivation because they lack knowledge about traditional forms of shifting cultivation and because they lack tenure security.

Since the early 1980s, the transmigration programme has turned increasingly to tree crops (rubber, coconut, oil palm, etc.) in place of food crops, on the assumption that this is generally a more suitable and profitable form of land use in the outer islands. The turn to tree crops is also important because it contributes to the effort to diversify to non-oil exports (RePPProT 1990: 41). Tentative projections showed that smallholder net income would be twice as high on tree crop schemes as compared to food crop schemes once fully developed (World Bank 1988: xxxix). No national data are available showing the extent to which the trend to tree crops may have alleviated the tendency to seek income outside the transmigration site. Case studies from Riau province in Sumatra, however, present a discouraging picture (see Holden and Hvoslef 1995; Holden et al. 1995).

\section{Land pressure induced by transmigration.} Transmigration settlements are often established adjacent to, or sometimes in the midst of, existing communities of shifting cultivators. Settlements thus can reduce the amount of land available in traditional clan rotations for shifting agriculture. Combined with increasing indigenous population pressure, this can contribute to the problem of shortened fallows, overuse of poor soils, the turn to sedentary agriculture and speculative land acquisition. Angelsen (1995) has observed this tendency in Riau province, Sumatra.

\section{Effects of spontaneous transmigration}

Dating from the mid-1980s, it seems there was substantial growth in the number of spontaneous transmigrants as compared to regular transmigrants (Dick 1991: 27-28). This appears to have happened for two reasons. First, infrastructural development for the regular transmigration programme in the early 1980s attracted spontaneous migrants. Second, the regular transmigration programme was scaled back in 1986 because of declining oil revenues and because a decision was made to devote scarce funds to upgrading infrastructure and production systems at existing transmigration sites (World Bank 1988: xxii-xxiii; Thiele 1994: 191). Tomich and van Noordwijk (1995: 3-4) suggest that spontaneous transmigrants have been quick to adopt the indigenous rubber production systems in Sumatra.

According to Dick (1991: 29), spontaneous transmigrants clear an average of 4.25 ha per family. On the basis of this figure, he calculates that spontaneous transmigrants are now the single most important cause of deforestation, accounting for approximately 178,500 ha per year of lost forest cover. This may be an over-estimate seeing that - as in the case of regular transmigrants - Dick assumes that all the land cleared is forest land, whereas this is not necessarily the case.

Among the main questions that surface from the foregoing information are the following: (1) How has the effect of transmigration on forest cover changed with the turn away from food crops and towards tree crops? (2) Has this change increased the stability and profitability of transmigrant income? (3) If it has done so, does this in turn induce a larger stream of spontaneous transmigrants? (4) Does a growing number of transmigrants necessarily undermine traditional shifting cultivation and how is this question related to the issue of land markets, formal tenure and traditional (adat) land rights?

\section{Population density}

Fraser (1996) makes the case that growth of population density is the fundamental explanation for deforestation in Indonesia. Data on population density by province in Indonesia show a strong inverse relationship with forest cover (Table 3). Several writers have observed this relationship (FAO 1990: 10; Barbier et al. 1993 : 7; Fraser 1996). ${ }^{18}$ Fraser $(1996: 6,15)$ states that for every $1 \%$ increase in population (the rate in the outer islands is 3\%), there is an approximate decrease of forest cover of $.3 \%$. The overall annual decrease of forest cover is thus $1 \%$, which corresponds to the annual forest cover loss of 900,000 to 1 million ha observed by FAO.

There is no doubt that a growing human presence in rural Indonesia has a role in deforestation. It remains to be demonstrated conclusively, however, that growing population density is the main cause of forest cover removal, as claimed by Fraser (1996) and others. It is not clear to what extent the high inverse correlation between population density and forest cover is causal, and to what extent it is incidental. It is possible there are other variables, excluded from Fraser's bivariate measure, that contribute to high correlation. Some writers have noted that in South-east Asia - and in the humid tropics in general - there is a typical sequence whereby forests are first cleared by loggers and then occupied for agriculture (Grainger 1993: 70; Kummer and Turner 1994). If this is the case, then it is possible to argue that logging is a "cause" of deforestation and shifting cultivators merely fill a "vacuum" created by the loggers, in those areas where this sequence takes place. This line of reasoning reverses the path of causation: opening of forests leads to an increase of

\footnotetext{
18 Jepma and Blom (1992: 209) conduct a modelling exercise that shows a strong potential positive effect on forest cover from a reduction of the population growth rate from $1.6 \%$ to $1.0 \%$.
} 
Table 3: Population density and forest cover by Province in Indonesia (1982) (ranked in ascending order of population density)

\begin{tabular}{lcc}
\hline Province & $\begin{array}{c}\text { Pop. density } \\
\text { (persons/km2) }\end{array}$ & $\begin{array}{c}\text { Total Forest Cover } \\
(\%)\end{array}$ \\
\hline Irian Jaya & 4 & 84 \\
East Kalimantan & 6 & 85 \\
Central Kalimantan & 7 & 73 \\
West Kalimantan & 18 & 59 \\
Central Sulawesi & 20 & 64 \\
Maluku & 22 & 81 \\
Riau & 25 & 62 \\
South-east Sulawesi & 27 & 65 \\
Jambi & 29 & 52 \\
Bengkulu & 42 & 57 \\
South Sumatra & 45 & 33 \\
DI Aceh & 50 & 79 \\
South Kalimantan & 58 & 49 \\
West Sumatra & 84 & 61 \\
North Sulawesi & 85 & 60 \\
South Sulawesi & 101 & 46 \\
North Sumatra & 123 & 39 \\
Lampung & 145 & 18 \\
East Java & 632 & 23 \\
West Java & 680 & 17 \\
Central Java & 760 & 15 \\
\hline
\end{tabular}

Source: Fraser (1996: 8)

population density in a given area, not the other way around. 19

There is another weakness in Fraser's neoMalthusian argument. There are various independent variables (technological change, distribution of wealth and income, demand for agricultural products, growth of infrastructure, level of women's education and participation in the labour market, etc.) that modify the influence of population on forest cover. If these variables are taken into account, the apparently fundamental role of population growth in the loss of forest cover is not so clear. It is possible, for example, for rural population to stay the same or decline (due to urbanisation), and for forest cover removal to increase because of higher per capita urban or international demand for agricultural production.

Non-Malthusian explanations, however, also have their weaknesses. Angelsen (1995) uses case study data from Sumatra to make the point opposite to that being made by Fraser (1996) - namely, that increasing population is not necessarily the main cause of defor- estation. He weights the factors causing annual forest clearing and finds the following: (1) the changing proportion of households opening swidden lands accounts for $70 \%$ of the total; (2) the total population of households accounts for $23 \%$ of the total; and the average size of swiddens accounts for $7 \%$ of the total (Angelsen 1995: 1724). This kind of analysis suggests that population growth explains approximately one-quarter of forest cover removal. Is it possible, however, that as in the case of Fraser's (1996) analysis, an alternative view of the linkages among relevant variables can produce a different conclusion? Is it possible, for example, that the increasing proportion of households opening swidden lands (said to be $70 \%$ of the explanation) is doing so in response to growing local population density and pressure? It is interesting to note that in Angelsen's (1995) survey, three-quarters of the farmer respondents believe that population growth explains shortages of land.

Further research on the relationship of population to deforestation would be useful, but it must be done in

19 There are other factors that can be seen to reverse the path of causation, including the logging-shifting cultivation tandem, improved road accessibility, and push migration to the frontier. (Personal communication, Arild Angelsen, 9 July 1996.) 
such a way as to clearly distinguish causal and incidental relationships, clearly account for all significant paths of causation, and adequately define what forms of agency are being assumed. Perhaps the most important step towards raising the sophistication of such analyses is to ask what causes increasing population growth, population density and migration - that is to say, to treat population as an intervening variable, rather than as an independent variable.

\section{LOGGING AND THE TIMBER INDUSTRY}

The forests of Indonesia are being logged at a rate of roughly 40 million cubic metres per year (m cum/yr), whereas the "sustainable" rate recommended by the Ministry of Forestry is $22 \mathrm{~m}$ cum/yr (World Bank 1995: i). Reportedly only a small portion of forest concessions are conducting enrichment planting. Some believe the development of the timber industry is being achieved at too great an economic and environmental cost to Indonesia (Gillis 1988: 181-2; Ahmad 1995) and that the overall contribution to economic development is low (Hariadi 1993; Ahmad 1995).

The estimates of deforestation caused directly by logging range from 77,000 ha to 120,000 ha annually (Table 2), which is approximately $10-20 \%$ of the total area deforested, and $10-15 \%$ of the 800,000 ha logged annually. ${ }^{20}$ In none of the studies is it specified in what sense logging is assumed to cause deforestation. It is not known if the studies measure this phenomenon in terms of : (1) clear-felling on lands designated for nonforest uses, ${ }^{21}(2)$ areas under bad silvicultural management, leading to invasion by imperata grasses or forest fires; (3) areas where conversion to agriculture has been inadvertently facilitated through logging and through non-enforcement of concession boundaries; or some combination of the above. While the studies fail to specify this crucial information, they imply that inadequate concession management and a short-term investment horizon on the part of concessionaires play a crucial role in this form of deforestation.

Why do some concessionaires exploit forests at an unsustainable rate, fail to manage their sites appropriately, and have no view to long-term investment? Most explanations point to a variety of government policies and practices that they view as inadequate and that must be reformed. The inadequacies can be classed in terms of the three following phenomena.
(1) The method of concession allocation gives too much land to concessionaires. Certain concessionaires thus have low incentives to prevent encroachment by smallholders, or are unable to stop such encroachments. Thiele (1994: 187) says low concession fees induce concessionaires to acquire vast areas, "more for insurance purposes or speculation than for timber harvesting". He adds "this not only implies that public resources are lying idle but also that deforestation by shifting cultivators is encouraged, because concessionaires have little incentive to control encroachment if they have excess area". In addition, the timber royalty fees in Indonesia are based largely on the volume of extraction rather than on the area of concessions, thus abetting the tendency to have overly large concession areas.

(2) Certain policies encourage rent-seeking behaviour and thus undermine incentives for long-term management. The rate of royalty payments to the government is low, meaning that concessionaires are able to capture a large share of the potential rents of concessions. According to Thiele ( 1994: 190) "high potential excess profits encourage 'rent seeking' activities in acquiring concessions and open the way for corruption so that the enforcement of concession agreements is endangered". Low royalty fees, in combination with 20 -year limits on the concession period, lead to the problem of "premature re-entry", where concessionaires re-enter their site after the first cut and prior to the expiry date, thus damaging immature timber stands. ${ }^{22}$ Ascher (1993: 2) suggests low rent capture encourages bad management not only because forest resources are under-valued, but also because concessionaires are in a hurry to extract timber for fear that the present favourable royalty rates might increase. In 1990 surveys found that up to $40 \%$ of the standing stock was damaged in logged concessions, thus greatly reducing their value and undermining incentives to protect them from encroachment and fire (World Bank 1990: xxi). Low royalty fees and high export taxes on logs and wood products from Indonesia depress their domestic price, thus limiting interest in replanting (World Bank 1995: ii, 8). ${ }^{23}$ Ascher (1993: 4) says considerations other than quality of concession management enter into the concession renewal process, thus undermining incentives for good performance.

(3) There is insufficient support for provincial-level protection offorests. Provincial-level governments

\footnotetext{
${ }^{20}$ Flint (1994: 1044) observes that, for South-east Asia as a whole in the 1880-1980 period, logging explains approximately $22 \%$ of deforestation.
}

21 Concessionaires are allowed to clear-cut, and are exempt from selective felling regulations, on lands where the area of the concession overlaps with conversion forests (Potter 1996: 19).

- 22 Note that the Indonesian government is presently considering an extension of the concession period to 70 years.

23 The price of logs in 1995 was $2530 \%$ of international parity value (World Bank 1995: ii). 
receive a low share of royalty fees collected by the national government which, as explained above, are already quite low. The World Bank (1995: 19) explains that "governments in provinces with extensive forest cover may be encouraged to replace forest with other forms of land use more able to generate revenue at the provincial level, or at least provide more income opportunities to communities living near the forests whose income might otherwise become a burden on provincial resources". There is the additional problem that forestry personnel are disproportionately concentrated in Java, rather than in the outer islands, where there are far greater forest resources. ${ }^{24}$

Commentators on the Indonesian forest situation make the case that concession management could be improved through the following policy reforms:

- substantially raising royalty fees and government rent capture (Gray and Hadi 1990; World Bank 1990: xx; Ascher 1993; D'Silva and Appanah 1993; Ramli and Ahmad 1993; Thiele 1994; Ahmad 1995; World Bank 1995);

- engthening the concession cycles and increasing tenure security for concessionaires (World Bank 1990: xx; D'Silva and Appanah 1993; Thiele 1994, 1995; World Bank 1994, 1995; Kartodihardjo 1995);

- enhancing competition in the allotment of concessions (Gray and Hadi 1990; Thiele 1994); and

- increasing the amount of area-based as compared to volume-based concession fees (Gray and Hadi 1990; Thiele 1994), among other measures.

It is argued that these policy changes could encourage improved custodianship of production forests, as well as produce substantial revenues for government, a portion of which could be used to enhance enforcement of forest laws.

If this is the case, then why are there not stronger interests within the government to ensure that these kinds of policy reforms are enacted? Ascher (1993), Dauvergne (1994), King (1996) and Ross (1996) argue that the answer to this question is essentially political. Ascher (1993) argues that the Government and the Ministry of Forestry view forests as an asset to be liquidated in order to diversify the economy; rent capture is kept low to facilitate this process. Dauvergne holds essentially the same view (1995: 503-507), that deforestation is fundamentally rooted in Indonesia's political structure and process, and government decisionmakers "view forests as a valuable, yet expendable resource, useful for generating foreign exchange to finance industrialization". Ross (1996) says that in many developing countries, including Indonesia, forest concessions are allocated as a form of political patronage to influential people within the "governing coalition". He adds that "the timber industries of developing states are almost always in the hands of allies of the governing coalition; the government, in turn, is loathe to act against the industry's interests" (Ross 1996: 170). King (1996: 216) sees improved management of the forest sector as blocked by the patrimonial characteristics of the Government, and that significant reform will likely require a "regime change, a critical shortage in timber supply, or external threats to Indonesia's exports of forest products".

While there may be an element of truth to these explanations, they do not satisfactorily answer why there are some concessionaires who are said to conform to forestry laws, do manage their sites well and do replant. Comparative research on concessionaires would be of great use in trying to better understand the role of logging and the timber industry in Indonesia's forest cover change.

An additional area of useful research would be the forest management implications of multi-sectoral investments. What are the practical consequences of the fact that some of the larger concessionaires have investments not only in forestry, but also in other sectors of the economy? Is it possible that timber exploitation serves as a form of "seed capital" for other industries, thus undermining incentives for long-term conservation? Conversely, is it possible that forest sector investment is a crucial adjunct to extra-sectoral investments, thus requiring certain concessionaires to maintain forests on a sustainable basis?

\section{ESTATES AND PLANTATIONS}

There are huge discrepancies in the estimates of deforestation resulting from the growth of estates and plantations (see Table 2). The estimates range from a low of $11,400 \mathrm{ha} /$ year to $274,000 \mathrm{ha} / \mathrm{year}{ }^{25}$ It is unclear whether the term "estate crops" is limited to cash crops on estates, or whether it also includes forest estates and plantations.

\section{Cash crops on estates}

There has been substantial growth in the area of land devoted to cash crop production in Indonesia in the last decade. The cash crop sub-sector was relatively undeveloped in the early years of the Suharto government, but has been actively promoted since the early 1980s in connection with the mandate to develop non-oil export revenue (Economist Intelligence Unit 1995a: 27). Whereas the food crop sub-sector is almost wholly composed of smallholders, the cash crop sub-sector is

\footnotetext{
${ }^{24}$ In $199050 \%$ of the forest department staff were in Java, even though Java has $2 \%$ of all forest land in the country (World Bank 1990: xxi).

${ }^{25}$ Low estimates are from TAG (1991) and Dick (1991), and high estimate is from FAO (1991) as cited in World Bank (1994: 52).
} 
composed of smallholders, large private commercial estates and state-owned plantations (Economist Intelligence Unit 1995a: 27).

African oil palm merits special attention in the context of land use change because of its phenomenal rate of growth. In 1994 there were 1.2 million ha of oil palm in private and government estates - by far the largest area in estates for all crops in Indonesia (PDP 1996: 55-56). The area of oil palm in estates has grown twelve-fold from 106,000 ha in 1967 to approximately 1.3 million ha in 1995 (DJP 1995: 4). ${ }^{26}$ Palm oil output increased more than ten-fold from 397,000 tons in 1975, to over 4 million tons in 1994 (Larson 1996: 32). Indonesia is one of the lowest-cost producers of vegetable oil in the world, thus motivating new investment in oil palm (Larson 1996: 1).

There is little available information on how much of the expansion of area in estates is taking place at the expense of forest cover. A study by Osgood (1994) claims there is a statistical relationship between the growth of estates and deforestation in Indonesia, but it yields little in the way of specific information. In 1990, the World Bank (1990: 34) said estate crop development was consuming a relatively small area of primary forest compared to transmigration, ${ }^{27}$ but noted emerging difficulties in locating new estates on non-forested land, and rapidly increasing demands for converting land to estates. At that time the government was launching the nuclear estate and smallholder programme (Perusahaan Inti Rakyat or PRI), a credit scheme for the establishment of private estates in which $40 \%$ of block-planted land would be for estates and $60 \%$ for smallholders. In the course of REPELITA III and half of REPELITA IV (roughly 1979-1987), 864,000 ha were assigned for these purposes, located on land targeted for conversion, not all of it forested land (World Bank 1995: 35). These data are difficult to reconcile with the claim of Hill (1994: 204) that most of the production increase from private estates since the early 1980s is attributable to the application of new technologies rather than to the expansion of area used; he adds that only in the case of oil palm has there been significant increase of the area planted.

The government estimates there are 40 million ha available in the outer islands for conversion to cash crop cultivation (Economist Intelligence Unit 1995a: 27). This suggests strongly there will be additional pressure for converting forests to this form of land use. The government is clearing a 1.2 million ha site in
Central Kalimantan for large-scale agricultural production of rice and other crops (McBeth 1995), and there are plans for considerable expansion of tree crop estates, notably oil palm.

\section{Forest plantations}

Dating back to the late 1980s there have been ambitious plans to expand the area of timber plantations. As of December 1995, only 520,000 ha of timber plantations had been established. ${ }^{28}$ The objective of the government has been to establish 1.4 million ha by $1990,1.8$ million ha by $1995,2.3$ million ha by 2000 and 10.5 million ha by 2030 (World Bank 1995: 8). The aim has been to supply Indonesia's emerging pulp and paper industry in the short term and eventually a portion of the needs of the wood products industry (p. 8). Pulp and paper mills presently rely heavily on natural forests, but these forests are getting further from the reach of mills as time passes (p. 8). Progress towards establishment of plantations for pulp and paper will be affected by the performance of the industry and by the notoriously volatile price of these products. It is estimated that a plantation area of 2 million ha can supply all of Indonesia's anticipated pulpwood needs by the year 2020 (p. 9). The establishment of plantations for timber is being held back by the low price of logs; only plantations on the most productive sites will be profitable (p. 8). Forest plantations have become a new pole of development for transmigration. Transmigrants are to be resettled to work either on plantations or in pulp and paper mills.

WALHI (1992: 2-3) and Belcher and Gennino (1993: 15) point out that the establishment of plantations, although reportedly aimed at safeguarding natural forests, may actually be contributing to the destruction of natural forests. They make an important point. Pulp and paper mills (as well as other wood products industries) are established with the expectation that raw materials will be supplied from plantations. ${ }^{29}$ However, if these supplies do not materialise sufficiently fast, then pressure on natural forests may be increased. It would be well worthwhile to research whether the growth of the pulp and paper industry, as well as other wood-processing industries, are in fact increasing exploitation of natural forests, or whether they are laying the foundation for a turn to sustainable plantation-based production.

\footnotetext{
${ }^{26}$ If one includes smallholders, the total area of oil palm is approximately 2 million ha in 1996 (DJP 1995: 4). The projected distribution for 1995 is: smallholders (656,099 ha or 33.6\%); government estates $(390,355$ ha or $20.0 \%)$; and private estates $(905,166$ ha or $46.38 \%$ ) (DJP 1995).

${ }^{27}$ Reportedly 46,000 ha of forest land was cleared for the estate crop sector during REPELITA III (1979-1984) (World Bank 1990: 34).

- $\quad{ }^{28}$ Report of the Ministry of Forestry's Directorate for Forest Management Supervision, as reported in the Jakarta Post, 9 April 1996.

${ }^{29}$ Porter (1994: 434) comments on the danger that pulp and paper mills in Indonesia will be consuming large areas of natural forest.
} 


\section{GUIDELINES FOR THE DETERMINATION OF RATES AND CAUSES}

In the foregoing we have seen that past attempts to discover the rate of change and causes of deforestation have been hampered by:

- Unstated, unclear, or mutually inconsistent definitions of key terms and concepts such as "forest", "deforestation" and the agents of forest cover change.

- Absence or lack of adequate baseline data and timeseries data on forest cover change.

- Lack of basic knowledge on the social characteristics of agents of forest cover change.

- Erroneous and tendentious reasoning and selective interpretation of information, facilitated by the lack of clarity in the use of key terms/concepts and the absence or inadequacy of data.

We suggest that future efforts to determine rates and causes of forest cover change be based on the following guidelines.

\section{Rates of forest cover change}

Rates of forest cover change should be based on comparison of satellite imagery of land cover at two (or more) points in time. ${ }^{30}$ The method of image creation should be matched, so as to avoid misinterpreting differences of resolution, texture or colour as forest cover change. Ideally, the past image(s) should be sufficiently old for differences of forest cover to be perceived clearly, and the new image should be sufficiently recent so that the measure of change captures relevant new phenomena.

The definitions of key terms must be clear and applied consistently across all aspects of the rate measurement. We recommend use of the definitions for "forest" and "deforestation" employed by FAO (1996) in their Forest Resources Assessment 1990: Survey of Tropical Forest Cover and Study of Change Processes." "Forest" is defined as "natural forest" (including both continuous and fragmented forests); "non-forest" refers to "other wooded lands" (including shrubs and short fallow); and "man-made woody vegetation" includes plantations (both forest and agricultural) (p. 20).

The study uses three-tiered definitions of "forest" and "forest cover change" in view of the varying purposes of researchers. "Forest" is defined either as: "closed forest"; "closed + open $+2 / 3$ fragmented forest"; or as "closed + open forest + fragmented forest + long fallow" (p. 20). "Forest cover change" is defined as follows (p. 22):

- Gross deforestation is calculated as "the sum of all area transitions from natural forest classes (continuous and fragmented) to all other classes".

- Net deforestation is calculated as "the area of gross deforestation minus all area transitions into natural forest classes from all other classes".

- Net degradation of natural forest is calculated from the area transitions among natural forest classes, by adding all change corresponding to degradation minus those corresponding to ame/ioration. ${ }^{32}$

We recommend close consultation of the methodology and technical specifications in the FAO (1996) study, both because they are a considerable improvement on past practice, and also because a uniform methodology offers the possibility of cross-regional and cross-national comparisons of trends.

Finally, we urge that analysis of the extent and rate of forest cover change give proportionate attention to the issue of degradation. Past studies have tended to emphasise deforestation to the exclusion of degradation. This tendency ignores the fact that degradation (in which the timber industry has a large role) is often a precursor to deforestation (defined as permanent forest cover removal) by other forms of agency.

\section{Causes of forest cover change}

Determination of the cause of forest cover change poses large conceptual and methodological challenges. Ascertaining cause is difficult because it involves demonstrating linked patterns of cause and effect through time, and there are often few data to prove these linkages. As we have noted earlier, several forms of agency may operate in the same location, making it difficult to disaggregate the effect of one from the other. We suggest the following guidelines for the improvement of determination of cause of forest cover change.

\footnotetext{
${ }^{30}$ For information on methodological developments in the assessment of forest cover change see especially Downton (1995) and FAO (1996).

${ }^{31}$ There are now various definitions of "forest" and "deforestation" that have emerged in FAO publications over the years (see discussion of this in UNESC 1996: 6-7).

${ }^{32}$ Degradation is defined as "decrease of density or increase of disturbance in forest classes" and amelioration is defined as "increase of density or decrease of disturbance in forest classes" (FAO 1996: 21).
} 


\section{Levels of causation}

Causation should be specified at three levels of explanation: agent; immediate cause; and underlying cause. ${ }^{33}$ The agent refers to the people or organisations (e.g., smallholders, logging companies, plantations) that have a physical role and/or a proximate decision-making role in forest cover change. The immediate causes of forest cover change are those decision parameters that have a direct influence on the behaviour of the agents. Examples of such parameters are: relative prices; relative access to resources and markets; availability of technology; rules regarding resource use; and cultural traditions. The underlying causes of forest cover change are those overarching national, regional, or international forces that can govern the influence of decision parameters. Examples of such forces are social structures, power relations, patterns of capital accumulation, terms of trade, and demographic and technological changes. Observe in Table 1 that early assessments of causation focused on agency, whereas later formulations gave attention to agency and to underlying causes.

\section{Interaction or independence of agents}

As mentioned earlier, it is possible for various kinds of agents to operate in the same location. It is also possible for agents to operate in separate locations and to have little contact with one another. It is important to specify these forms of interaction or independence in assessing causation.

In cases where different agents operate in the same location, there are likely to be important interaction effects that either increase or decrease forest cover change. Increased change might happen in cases where competition for access to land increases land rents and weakens customary land rights, as has happened in Riau province, Sumatra (Angelsen 1995: 1722-1724). Decreased change might happen in cases where (for example) shifting cultivators successfully defend their traditional forests against encroachment by loggers. ${ }^{34}$ Conversely, in cases where forms of agency operate independently of one another, there may be factors that facilitate or inhibit forest cover change. For example, there may be forest dwellers whose lands are relatively well protected from encroachment because they live in remote primary forests on hilly terrain that are relatively inaccessible to timber companies.

Little is known about the geographical distribution of forms of agency and their interactive (or synergistic) effects on forest cover change. Information on this subject is sketchy and may be out of date. Weinstock and Sunito (1989: 50) say 39.8\% of shifting cultivation is taking place "on lands of critical concern to the management of production forests". Sutter (1989: 13) estimates $85 \%$ of annual deforestation occurs in conversion and production forests (but agency is not specified). World Bank (1990: 6) data show there is a larger area of open forest canopy in production forests (both "limited" and "regular") compared to reserves and protection forests, but here again there is not sufficient information to know the cause. It will be useful to achieve a greater understanding of these effects, especially in view of increasing competition for access to land in the outer islands, and the growing role of estates and plantations in forest cover change.

\section{Satellite imagery/GIS assistance}

In certain cases, satellite imagery and GIS mapping can assist in determining patterns of causation. For example high resolution imagery (accompanied by ground truthing) can document a change from natural forest cover to a monoculture oil palm plantation. In this case the "cause" (defined here in the sense of ultimate non-forest land use) is clear. However there are many cases where the change from closed to fragmented natural forest conveys little visual information about cause, even in cases where high-resolution imagery is available. In these cases, social science research is necessary to achieve a full understanding of the reasons for forest cover change. It is important to know the capabilities and limitations of imagery and GIS technology in undertaking research on causation.

\section{Macro-economic causation}

Indonesia is presently noted for the relative stability and resilience of its economic situation. Macro-economic restructuring policies have been implemented since the 1970s in response to world-wide oil shocks that affected the economy dramatically and that have had repercussions until the present. Indonesia is viewed as a case of successful macro-economic adjustment, inasmuch as the overall policy of deregulation, export diversification and currency devaluations are credited with maintaining high rates of economic growth.

It is not known what net effects these policies have had - whether positive or negative - on forest cover in the country. These adjustment policies and other macro-economic conditions (prices of key commodities, level of debt, terms of trade of agriculture and the rural sector) have not yet been studied adequately in relation to the livelihoods of people in forest communities and forest condition. ${ }^{35}$ Modelling exercises by Jepma and Blom (1992) and Thiele (1995) make interesting inroads on this topic. Future research should

33 This formulation combines ideas suggested by Arild Angelsen and David Kaimowitz.

${ }^{34}$ Personal communication with Kevin Jeanes, Team Leader, Danau Sentarum Wildlife Reserve Conservation Project, West Kalimantan, October 1996. 
examine the net effect of various macro-economic conditions on forest cover, via their effect on smallholders (migration patterns and farming system choices), large farmers (investment decisions at the forest frontier) and concessionaires (incentives for long-term management of primary forests).

\section{SUMMARY AND CONCLUSION}

Some degree of deforestation in Indonesia is necessary to satisfy growing demand for food production and other activities related to economic development. The government of Indonesia has designated conversion forests (approximately one-quarter of total forest land) as areas appropriate for deforestation. Deforestation and degradation, however, go well beyond the boundaries of conversion forests, and there have been some notable problems with inappropriate land use designations. The RePPProT study (1990: 36), for example, found that 30.8 million ha of production forest should be reclassified as protection forest.

In order to adequately address the problems posed by inappropriate forest cover loss in Indonesia, it is necessary to know the rate of forest cover change and its causes. It is necessary to resolve certain fundamental ambiguities concerning the rate and causes of deforestation in Indonesia. A clearer understanding of the situation is a necessary precondition for formulating new policies and adapting existing policies aimed at improving the welfare of forest communities and the conservation and management of Indonesia's forests.

Towards this end, the main questions to be addressed are the following:

(1) How are we to define "forest", "deforestation" and "agency" in the context of Indonesia? This is a fundamental step not only for interpreting the information that exists, and for forming a cogent theoretical base for conducting further research, but also for establishing a "common language" among researchers and policy makers. We suggest researchers adopt the terms and methodology proposed by FAO (1996) in addressing this issue.

(2) What are the socio-economic characteristics and land-use practices of the various agents that have been lumped under the term "shifting cultivation"? Related questions are: What are the proportions of the various kinds of smallholders who farm in the forest or at the forest margin (i.e., shifting cultivators, forest pioneers and tree crop producers)? What are the geographic areas where these smallholders tend to operate? What is the relationship of levels of livelihood (i.e., the search for subsistence vs. the search for additional household income) with forest conservation?

(3) Is the relationship between increasing population density and loss of forest cover causal or incidental? There is considerable practical content in the answer to this question, given that decisions will continue to be made on where transmigrants will and will not be sited, and where settlement in general will or will not be allowed. Useful interpretation of inverse correlations between population density and forest cover must be based on a clear and consistent conceptualisation of agency in deforestation, acknowledgement of population as an intermediate variable and recognition of all relevant independent variables.

(4) Why do some concessionaires reportedly maintain their sites well, while others do not? Related questions are: To what extent would certain proposed policy reforms (increased government rent capture, lengthened concession cycle and tenure security, enhanced competition for access to concessions, increase of areabased fees) improve the performance of concession management? What is the nature of state interests in connection with the long-term conservation and management of primary forests?

(5) What have been the net forest cover effects of macro-economic restructuring and changes of commodity prices since the early 1980' s? Answers to these and other questions at the macro-economic level will have great practical value for shaping reforms in existing sectoral, as well as extra-sectoral policies.

Beyond addressing these questions, future research on the extent and causes of deforestation in Indonesia should observe two principles that surface from a review of analysis conducted to date (see Table 1). First, it should be recognised that several forms of agency have a significant role in the process of forest conversion. Researchers should therefore rise above a general tendency to identify one primary cause and to do so to the exclusion of sufficient attention to other causes. Policy solutions to inappropriate forms of deforestation that focus on only one form of agency will surely fail to meet their goal, because they would under-appreciate the complexity of the problem.

Second, future research should continue the trend, begun after 1990 (see Table 1), of going beyond analysis limited to the agents of forest cover removal (transmigrants, forest pioneers, loggers, etc.). If the immediate and underlying causes of land-use change are to be adequately understood, then it is necessary to analyse the broader political, economic and social trends, at the local, regional, national and international levels, that influence behaviour at the forest margin.

\footnotetext{
35 Among references discussing the effect of macro-economic conditions on certain agricultural commodities, see: Barlow and Muharminto (1982: 88, 112); Nancy (1988); Siebert et al. (1994); Angelsen (1995).
} 


\section{Acknowledgements}

The authors wish to express their gratitude to the following individuals who generously gave their time to give comments on drafts of this paper: Arild Angelsen, Chris Bennett, Neil Byron, Dudung Darusman, Chris Elliott, Erwidodo, David Kaimowitz, Plinio Sist, Titus Sarijanto and Jeff Sayer. We accept responsibility for any errors of fact or interpretation that may remain in the final product.

\section{REFERENCES}

Ahmad, M. 1995. The Role of Timber Production in Indonesian Economy: Reality or Illusion? Konphalindo, Jakarta.

Angelsen, A. 1995. Shifting cultivation and "deforestation": a study from Indonesia. World Development 23(10):1713-1729.

Ascher, W. 1993. Political economy and problematic forestry policies in Indonesia: obstacles to incorporating sound economics and science. The Center for Tropical Conservation, Duke University. July.

BAPPEDA dan PPKD. 1995. Profil Ladang Berpindah di Kalimantan Tengah. BAPPEDA Propinsi Dati I Kalimantan Tengah dan Pusat Penelitian Kebudayaan Dayak.

Barbier E.B., N. Bockstael, J.C. Burgess and I. Strand.1993. The timber trade and tropical deforestation in Indonesia. LEEC Paper DP 93-01. London Environmental Economics Centre.

Barlow, C. and Muharminto. 1982. The rubber smallholder economy. Bulletin of Indonesian Economic Studies 18(2): 86-119.

Barlow, C. and T. Tomich. 1991. Indonesian agricultural development: the awkward case of smallholder tree crops. Bulletin of Indonesian Economic Studies 27 (3): 29-53

Belcher, M. and A. Gennino. 1993. Southeast Asian Rainforests: A Resource Guide and Directory. Rainforest Action Network, San Francisco.

Chomitz, K.M. and C. Griffiths. 1996. Deforestation, shifting cultivation and tree crops in Indonesia: nationwide patterns of smallholder agriculture at the forest frontier. Research Project on Social and Environmental Consequences of Growth-Oriented Policies. Working Paper No. 4. The World Bank, Washington, DC.

Colfer, C.J. Pierce with R.G. Dudley.1993. Shifting Cultivators of Indonesia: Marauders or Managers of the Forest? Community Forestry Case Study Series 6. Food and Agriculture Organization of the United Nations, Rome.

Dauvergne, P. 1994. The politics of deforestation in Indonesia. Pacific Affairs 66(4): 497-518.

DepHut. 1995. Laporan: Inventarisasi dun Identifikasi Perladangan Berpindah/Perambahan Hutan Propinsi Kalimantan Timur Tahun Anggaran 1994/1995. Departemen Kehutanan, Kantor Wilayah Propinsi Kalimantan Timur, Samarinda.

DepTrans. 1995. Kontribusi Pembangunan Transmigrasi Pelita V. Pusat Data dan Informasi. Sekretariat Jenderal Departemen Transmigrasi dan Pemukiman Perambah Hutan, Republik Indonesia, Jakarta.

DepTrans dan YDWL. 1996. Upaya Penanganan Permasalahan Perambah Hutan di Propinsi Kalimantan Timur (Taman Nasional Kutai) dan Kalimantan Selatan (Sungai Pinang). Departemen Transmigrasi dan Pemukiman Perambah Hutan, Kantor Wilayah Propinsi Kalimantan Timur dan Yayasan Dharma Wana Lestari, Fakultas Kehutanan, Universitas Mulawarman, Samarinda.

Dick, J. 1991. Forest land use, forest use zonation, and deforestation in Indonesia: a summary and interpretation of existing information. Background paper to UNCED for the State Ministry for Population and Environment (KLH) and the Environmental Impact Management Agency (BAPEDAL).

DJP. 1995. Statistik Perkebunan Indonesia 1994-1996. Direktorat Jendral Perkebunan, Jakarta.

Dove, M.R.1993. Smallholder rubber and swidden agriculture in Borneo: a sustainable adaptation to the ecology and economy of the tropical forest. Economic Botany 47(2): 136-147.

Dove, M.R.1996. So far from power, so near to the forest: a structural analysis of gain and blame in tropical forest development. In C. Padoch and N.L. Peluso (eds), Borneo in Transition: People, Forests, Conservation, and Development. Oxford University Press, Kuala Lumpur. pp. 41-58.

Downton, M. W. 1995. Measuring tropical deforestation: development of the methods. Environmental Conservation 22(3): 229-240.

D' Silva, E. and S. Appanah. 1993. Forestry Management for Sustainable Development. EDI Policy Seminar Report No. 32. The World Bank, Washington DC.

Durand, F. 1994. Les Forets en Asie du Sud-Est: Recul et Exploitation. Le Cas de l' Indonésie. L'Harmattan, Paris. Economist Intelligence Unit. 1995a. Country Profile: Indonesia 1994-95. The Economist Intelligence Unit, London.

Economist Intelligence Unit. 1995b. Country Report: Indonesia 4th Quarter 1995. The Economist Intelligence Unit, London. 
Endogeotec Visicon. 1996. Studi pola migrasi perambah hutan. Lokasi: Sumatra Selatan dun Lampung. Endogeotec Visicon, Jakarta.

FAO. 1990. Situation and Outlook of the Forestry Sector in Indonesia. Volume 1: issues, findings and opportunities. Ministry of Forestry, Government of Indonesia; Food and Agriculture Organization of the United Nations, Jakarta.

FAO. 1996. Forest Resources Assessment 1990: Survey of Tropical Forest Cover and Study of Change Processes. FAO Forestry Paper 130. Food and Agriculture Organization of the United Nations, Rome.

Fasbender, K. and S. Erbe.1990. Towards a New Home: Indonesia' s Managed Mass Migration. Verlag Weltarchiv GMBH, Hamburg.

Flint, E.P. 1994. Changes in land use in South and Southeast Asia from 1880 to 1980: a data base prepared as part of a coordinated research program on carbon fluxes in the tropics. Chemosphere 29(5): 1015-1062.

Fraser, A.I. 1996. Social, economic and political aspects of forest clearance and land-use planning in Indonesia. Unpublished manuscript.

Gillis, M. 1988. The logging industry in tropical Asia. In J.S. Denslow and C. Padoch (eds), People of the Tropical Rainforest. University of California Press in association with Smithsonian Institution Traveling Exhibition Service, Berkeley. pp. 177-184.

GOI/FAO. 1996. National Forest Inventory of Indonesia: Final Forest Resources Statistics Report. Directorate General of Forest Inventory and Land Use Planning, Ministry of Forestry, Government of Indonesia and Food and Agriculture Organization of the United Nations, Jakarta.

Grainger, A. 1993. Controlling Tropical Deforestation. Earthscan, London.

Gray, J. and Soetrisno Hadi 1990. Fiscal policies in Indonesian forestry. Directorate General of Forest Utilization, Ministry of Forestry, Government of Indonesia and Food and Agriculture Organization of the United Nations, Jakarta. April.

Hariadi. 1993. Rendahnya kontribusi pengusahaan hutan terhadap pembangunan regional. (The low level of economic contribution of forest enterprises to the regional development.) Teknolog 6(2): 29-33.

Hasanuddin, L. 1996. Mitos-mitos pengelolaan hutan di Indonesia. Kertas Posisi No. 02. Wahana Lingkungan Hidup Indonesia / Friends of the Earth Indonesia.

Hill, H.1994. Indonesia's New Order: The Dynamics of Socio-economic Transformation. Allen \& Unwin, St Leonards, NSW, Australia.

Holden, S. and H. Hvoslef. 1995. Transmigration settlements in Seberida: causes and consequences of the deterioration of farming systems of settlers in a rain forest environment. In O. Sandbukt (ed.), Management of Tropical Forests: Towards an Integrated Perspective. Centre for Development and the Environment, University of Oslo. pp. 107-125.

Holden, S., H. Hvoslef and R. Simanjuntak. 1995. Transmigration settlements in Seberida, Sumatra: deterioration of farming systems in a rain forest environment. Agricultural Systems 49(3): 237-258.

Jepma, C.J. and M. Blom. 1992. Global trends in tropical forest degradation: the Indonesian case. WageningseEconomische-Studies 24: 185-2I4

Kartawinata, K., T.C. Jessup and A.P. Vayda. 1989. Exploitation in Southeast Asia. In H. Lieth and M.J.A. Werger (eds), Tropical Rain Forest Ecosystems. Elsevier Science Publishers, Amsterdam. pp. 59 1-6 10.

Kartodihardjo, H. 1995. Kegagalan teori rente ekonomi hutan. Prisma (2): 43-60.

King, D.Y. 1996. The political economy of forest sector reform in Indonesia. The Journal of Environment \& Development 5(2):2 16-232.

Kummer, D.L. and B.L. Turner II. 1994. The human causes of deforestation in Southeast Asia. Bioscience 44(5): 323-328.

Larson, D.F. 1996. A review of the palm oil subsector in Indonesia. International Economics Department, Commodity Policy and Analysis Unit, The World Bank, Washington, DC.

McBeth, J. 1995. Swamp for sale. Far Eastern Economic Review. September 7. pp. 58-59.

McClellan, S. 1992. Troubles of transmigration. Ceres 24(135): 38-41.

MOF. 1992. Indonesia Tropical Forestry Action Program. Ministry of Forestry, Republic of Indonesia, Jakarta.

MOF. 1995. Country Brief: Indonesia Forestry Action Programme (IFAP). Ministry of Forestry, Republic of Indonesia, Jakarta.

Myers, N. 1995. The world's forests: need for a policy appraisal. Science 268: 823-824.

Nancy, C. Pengaruh kebijaksanaan devaluasi terhadap ekspor karet alam Indonesia. (The influence of the devaluation policy on Indonesian rubber exports.) Bulletin Perkebunan Rakyat 4(2): 35-38.

Osgood, D. 1994. Government failure and deforestation in Indonesia. In K. Brown and D.W. Pearce (eds), The Causes of Tropical Deforestation: the Economic and Statistical Analysis of Factors giving rise to the Loss of. Tropical Forests. UCL Press, London. pp. 217-225.

PDP. 1996. Statistik Pertanian 1994. Pusat Data Pertanian, Departemen Pertanian, Jakarta.

Porter, G. 1994. The environmental hazards of Asia Pacific development: the Southeast Asian rainforests. Current History 93(587):430-434 
Potter, L. 1993. The onslaught on the forests in South-East Asia. In H. Brookfield and Y. Byron (eds), SouthEast Asia's Environmental Future: The Search for Sustainability. United Nations University Press, Tokyo and Oxford University Press, Kuala Lumpur. pp. 103-123.

Potter, L. 1996. Forest degradation, deforestation, and reforestation in Kalimantan: towards a sustainable land use? In C. Padoch and N.L. Peluso (eds), Borneo in Transition: People, Forests, Conservation, and Development. Oxford University Press, Kuala Lumpur. pp. 13-40.

Ramli, R. and M. Ahmad. 1993. Rente Ekonomi Pengusahaan Hutan Indonesia. Wahana Lingkunan Hidup Indonesia, Jakarta.

RePPProT. 1990. The Land Resources of Indonesia: A National Overview. Regional Physical Planning Programme for Transmigration (RePPProT). Overseas Development Administration, London and Department of Transmigration, Jakarta.

RI. 1994. Rencana Pembangunan Lima Tahun Keenam 1994/95-1998/99. Buku III. Republik Indonesia, Jakarta.

Ross, M. 1996. Conditionality and logging reform in the tropics. In R.O. Keohane and M.A. Levy (eds), Institutions for Environmental Aid: Problems and Prospects. MIT Press, Cambridge, Massachusetts. pp 167197

Saharjo, B.H. 1994. Deforestation with reference to Indonesia. Wallaceana 73: 7-12.

Sayer, J.A. and T.C. Whitmore. 1991. Tropical moist forests: destruction and species extinction. Biological Conservation 55: 199-2 13.

Secrett, C. 1986. The environmental impact of transmigration. The Ecologist 16(2/3): 77-88.

Siebert, S.F., J.M. Belsky and K. Rauf. 1994. Rattan management for sustainable livelihoods and forest conservation: the case of Kerinci-Seblat National Park, Indonesia . In M. Munasinghe and J. McNeely (eds), Protected Area Economics and Policy: linking conservation and sustainable development World Bank, Washington, DC. pp 125-132.

Soemarwoto, O. 1992. Peranan hutan tropik dalam hidro-orologi, pemanasan global dan keanekaan hayati. Dalam Mochtar Lubis (penyunting) Melestarikan Hutan Tropika: Permasalahan, manfaat dan kebijakannya. Yayasan Obor Indonesia, Jakarta. pp. 1-26.

Sutter, Harald. 1989. Forest Resources and Land Use in Indonesia. Indonesia Forestry Studies, Field Document No. I-1. Ministry of Forestry, Government of Indonesia and Food and Agriculture Organization of the United Nations, Jakarta.

TAG (Transmigration Advisory Group). 1991. Forest Clearance Study. Ministry of Transmigration, Jakarta.

Thiele, R. 1994. How to manage tropical forests more sustainably: the case of Indonesia. Intereconomics 29(4): 184-193.

Theile, R. 1995. Conserving tropical rain forests in Indonesia: a quantitative assessment of alternative policies. Journd of Agricultural Economics 46(2): 187-200.

Tomich, T.P. and M. van Noordwijk. 1995. What drives deforestation in Sumatra? Paper presented at Regional Symposium on "Montane Mainland Southeast Asia in Transition", Chiang Mai, Thailand, 13-16 November.

UNESC. 1996. Programme Element 1.2: Underlying causes of deforestation and forest degradation. Report of the Secretary General. E/CN.17/IPF 1996/2. 13 Feb. 1996. United Nations Economic and Social Council, New York.

WALHI. 1992. Violated Trust: Disregard for the Forests and Forest Laws of Indonesia. The Indonesian Environmental Forum (WALHI), Jakarta.

WALHI/YLBHI. 1992. Mistaking Plantations for Indonesia' s Tropical Forests. Wahana Lingkungan Hidup; Yayasan Lembaga Bantuan Hukum Indonesia, Jakarta.

Weinstock, J.A. and Satyawan Sunito. 1989. Review of shifting cultivation in Indonesia. Directorate General of Forest Utilization, Ministry of Forestry, Government of Indonesia and Food and Agriculture Organization of the United Nations, Jakarta.

Whitten, A.J. 1987. Indonesia's transmigration program and its role in the loss of tropical rain forests. Conservation Biology 1(3): 239-246.

World Bank. 1988. Indonesia: The Transmigration Program in Perspective. The World Bank, Washington, DC.

World Bank. 1990. Indonesia: Sustainable Development of Forests, Land, and Water. The World Bank, Washington, DC.

World Bank. 1994. Indonesia: Environment and Development. The World Bank, Washington, DC.

World Bank. 1995. The economics of long term management of Indonesià s natural forest. Unpublished manuscript. August.

World Bank. 1996. Indonesia: Dimensions of Growth. Report No. 15383-IND. Country Department III, East Asia and Pacific Region. The World Bank, Washington, DC.

Zerner, C. 1992. Indigenous forest-dwelling communities in Indonesia's outer islands: livelihood, rights, and environmental management institutions in the era of industrial forest exploitation. Unpublished manuscript. 